\title{
PHENOLIC CONTENT, ANTIOXIDANT AND IN VITRO ANTIDIABETIC EFFECTS OF THIRTEEN MARINE ORGANISMS FROM MEDITERRANEAN SEA
}

\author{
DIDEM DELIORMAN ORHAN ${ }^{1 *}$, NILUFER ORHAN $^{1}$, OZGE DEMIR $^{2}$, BELMA KONUKLUGIL $^{2}$ \\ ${ }^{I}$ Gazi University, Faculty of Pharmacy, Department of Pharmacognosy, 06330, Etiler Ankara, Turkey \\ ${ }^{2}$ Ankara University, Faculty of Pharmacy, Department of Pharmacognosy, 06100, Tandoğan Ankara, Turkey \\ *corresponding author: didemdeliorman@gmail.com \\ Manuscript received: January 2020
}

\begin{abstract}
The aim of the study was to evaluate the total phenolic content, in vitro antidiabetic and antioxidant potential of marine organisms collected from Mediterranean coast. Methanol extracts of one soft coral (Eunicella singularis) and twelve sponge species (Agelas oroides, Aplysina aerophoba, Axinella cannabina, A. polypoides, Cliona viridis, Dictyonella incisa, Dysidea avara, Ircinia incisa, I. oros, I. variabilis, Petrosia ficiformis, Sarcotragus spinulosa) were investigated for their enzyme inhibitory activities, total phenolic content, total antioxidant capacity, ferric reducing antioxidant power, metal chelating and radical scavenging activities. Dysidea avara was found to be the most active extract on $\alpha$-glucosidase enzyme (94.66 - 4.87\% for $3000-100 \mu \mathrm{g} / \mathrm{mL}$ ). Therefore, $\alpha$-glucosidase inhibitory activity of its major compounds avarol and avarone was tested and found to be $86.18 \pm 1.76 \%$ and $78.94 \pm 1.38 \%$ respectively, at $10 \mu \mathrm{M}$. The present study indicated that the sponge Dysidea avara can be evaluated as a new natural source in the treatment of diabetes mellitus.
\end{abstract}

\section{Rezumat}

Scopul studiului a fost evaluarea conținutului fenolic total, potențialul antidiabetic in-vitro și cel antioxidant al organismelor marine colectate de pe coasta mediteraneană. Extractele metanolice dintr-o specie de coral (Eunicella singularis) și douăsprezece specii de burete (Agelas oroides, Aplysina aerophoba, Axinella cannabina, A. polypoides, Cliona viridis, Dictyonella incisa, Dysidea avara, Ircinia incisa, I. oros, I. variabilis, Petrosia ficiformis, Sarcotragus spinulosa) au fost investigate privind activitățile lor inhibitoare enzimatice, conținutul fenolic total, capacitatea antioxidantă totală, potența reducătoare, chelarea metalelor și activitatea de scavenger. Dysidea avara s-a dovedit a fi cel mai activ extract, cu acțiune asupra enzimei $\alpha$-glucozidază (94,66 - 4,87\% pentru $3000-100 \mu \mathrm{g} / \mathrm{mL})$. Activitatea inhibitorie asupra $\alpha$-glucozidazei a compușilor avarol și avaronă s-a dovedit a fi de $86,18 \pm 1,76 \%$ și, respectiv $78,94 \pm 1,38 \%$ la concentrația de $10 \mu \mathrm{M}$. Studiul a arătat că Dysidea avara ar putea fi evaluat ca o sursă naturală în tratamentul diabetului zaharat.

Keywords: antidiabetic, antioxidant, avarol, avarone, coral, sponge

\section{Introduction}

Marine sponges have attracted a great interest in the scientific communities and they have been the subject of hundreds of phytochemical and biological activity studies in the last 60 years. Sponge secondary metabolites possess a large range of bioactivities and until now, more than 5000 different compounds have been isolated from about 500 sponge species [6, 22]. Sponges are mainly a source of unusual nucleosides, bioactive terpenes, sterols, cyclic peptides, alkaloids, fatty acids, peroxides and amino acid derivatives. Secondary metabolites of sponges have been found to interfere with pathogenesis of a wide range of diseases. Their biological activities can be classified as antiinflammatory, antitumor, immunosuppressive or neurosuppressive, antiviral, antimalarial, antibiotic and antifouling [35]. Turkey is surrounded by Black sea, the Aegean Sea and the Mediterranean Sea and has a long coastline which is $4200 \mathrm{~km}$ long. The total number of the sponge species in the Turkish marine fauna was reported to be 131 [40]. Although there are many studies on the biodiversity of marine organisms of Turkey, there are only a few studies on their biological activities and phytochemical profile $[1-3,13,16,18,27]$. Therefore, biological activity and phytochemical studies were conducted on the thirteen marine organisms from coasts of Turkey in this study. $\alpha$-Amylase and $\alpha$-glucosidase inhibitory activities, total antioxidant capacity, ferric reducing antioxidant power, metal chelating and [2,2'azino-bis(3-ethylbenzothiazoline-6-sulphonic acid)] (ABTS) radical scavenging activities of coral and sponge extracts were investigated and their total phenolic content was determined.

\section{Materials and Methods}

Collection of marine organisms. Sponge and coral samples were collected by scuba divers from reef in habitats at depths of $9-21 \mathrm{~m}$ from different locations 
FARMACIA, 2021, Vol. 69, 1

of Turkish coasts. Foreign materials and/or organisms were removed from samples with a knife. Samples were transferred as soon as possible to the laboratory in Ankara while kept in ethanol (70\%) during transfer and later on put in deepfreeze until the experimental process. Samples were deposited in the Department of Pharmacognosy, Faculty of Pharmacy, Ankara University, Turkey. The species investigated in this study are listed in Table I.

Table I

Collection sites, date and extraction yield of marine organisms

\begin{tabular}{|c|c|c|c|c|}
\hline Sample Name & Family & Location, City, Country & Collection Date & Yield \% \\
\hline \multicolumn{5}{|l|}{ Sponge Species } \\
\hline Agelas oroides & Agelasidae & Kemer, Antalya, Turkey & October, 2014 & 1.84 \\
\hline Aplysina aerophoba & Aplysinidae & Gölcük, Kocaeli, Turkey & April, 2013 & 2.23 \\
\hline Axinella cannabina & Axinellidae & Turgut Reis, Muğla, Turkey & April, 2013 & 2.55 \\
\hline Axinella polypoides & Axinellidae & Gökova, Muğla, Turkey & April, 2013 & 2.97 \\
\hline Cliona viridis & Clionaidae & Gölcük, Kocaeli, Tukey & April, 2013 & 3.34 \\
\hline Dictyonella incisa & Dictyonellidae & Seferhisar, İzmir, Turkey & October, 2013 & 3.91 \\
\hline Dysidea avara & Dysideidae & Ayvalık, Balıkesir, Turkey & October, 2013 & 3.50 \\
\hline Ircinia incisa & Irciniidae & Fethiye, Muğla, Turkey & July, 2013 & 3.03 \\
\hline Ircinia oros & Irciniidae & Fethiye, Muğla, Turkey & October, 2013 & 1.75 \\
\hline Ircinia variabilis & Irciniidae & Turgut Reis, Muğla, Turkey & April, 2012 & 1.29 \\
\hline Petrosia ficiformis & Petrosiidae & Gökova, Muğla, Turkey & April, 2013 & 2.71 \\
\hline Sarcotragus spinulosa & Irciniidae & Kemer, Antalya, Turkey & April, 2013 & 1.65 \\
\hline \multicolumn{5}{|l|}{ Coral Species } \\
\hline Eunicella singularis & Gorgoniidae & Ayvalık, Balıkesir, Turkey & October, 2013 & 1.23 \\
\hline
\end{tabular}

Extraction. Dried and chopped coral/sponge samples were extracted individually with pure methanol $(3 \times 50$ $\mathrm{mL}$ ). Each extraction was developed with mechanical shaking, in glass flasks at room temperature. Extracts were filtered and concentrated under vacuum on a rotary evaporator and lyophilized by a freeze dryer. The obtained methanol extracts were employed in the activity experiments and isolation procedures. Isolation of avarone and avarol. Avarol and avarone were isolated from the methanol extract of Dysidea avara as previously described. The structures of the compounds were established on the basis of spectroscopic data $\left({ }^{1} \mathrm{H}\right.$ NMR) and comparison with the standards on TLC [3].

Determination of total phenolic content

Total phenolic content was measured according to a previously published spectrophotometric protocol [41] by using Folin-Ciocâlteu reagent. The total phenolic content was expressed in mg of gallic acid equivalents/g extracts. Calibration curve equation was $y($ Abs. $)=5.306 \mathrm{x}$ (Conc. $)+0.0587$ with $\mathrm{r}^{2}=$ 0.9986 .

Bioactivity methods

Assay for scavenging activity of ABTS radical cation. ABTS [2,2'-azino-bis(3-ethylbenzothiazoline-6sulphonic acid)] radical cation $\left(\mathrm{ABTS}^{+}\right.$) scavenging assay was achieved by using the spectrophotometric methods of Re et al. and Meot-Duros et al. with slight modifications [20, 32]. Gallic acid was used as the positive control.

Ferric-reducing antioxidant power. The reducing power of the coral/sponge extracts was determined by the reducing power assay of Oyaizu [26]. Ascorbic acid was used as the positive control.
Metal chelating activity. Extracts were incubated with $\mathrm{FeCl}_{2}(2 \mathrm{mM})$. The reaction was initiated by the addition of ferrozine $(5 \mathrm{mM})$ and the total volume was adjusted to $4 \mathrm{~mL}$ with ethanol. After $10 \mathrm{~min}$, the absorbance was measured at $562 \mathrm{~nm}$. EDTA was used as a reference compound. The control contained $\mathrm{FeCl}_{2}$ and ferrozine [12].

Total antioxidant activity by phosphomolybdenum assay. Extracts were added to test tubes containing distilled water and molybdate reagent solution. Vortexed tubes were incubated at $90^{\circ} \mathrm{C}$ for $90 \mathrm{~min}$. Then, tubes were cooled to room temperature and the absorbances of the samples were measured at $695 \mathrm{~nm}$. Results were expressed as ascorbic acid equivalent [30]. Assay for $\alpha$-amylase and $\alpha$-glucosidase inhibitory activity. The $\alpha$-amylase inhibitory activity of the extracts was determined by the chromogenic method of Ali et al. [4]. Acarbose (Bayer Group, Turkey) was used as the positive control. $\alpha$-Glucosidase inhibitory activity of the extracts was determined by the method of Lam et al. [19]. Acarbose was used as positive control. Statistical analysis

All experiments were carried out with three replicates. Values were presented as means \pm standard deviation (S.D.) or standard error of the mean (S.E.M.). Statistical differences between the treatments and the controls were tested by one-way analysis of variance (ANOVA) followed by the Student-Newman-Keuls test using the "Instat" statistic computer program. A difference in the mean values of $p<0.05$ was considered to be statistically significant. Linear regression analyses were done using MS-DOS software (GraphPad InStat statistical program). Pearson's correlation coefficient was calculated using Microsoft excel 2016. 
FARMACIA, 2021, Vol. 69, 1

\section{Results and Discussion}

Total phenolic content of the sponge extracts ranged from 83.51 to $117.24 \mathrm{mg} \mathrm{GAE} / \mathrm{g}$ extract. The highest total phenolic content was determined in Axinella polypoides extract (Table II).

Table II

Total phenolic content, ferric reducing power, total antioxidant capacity and ABTS radical scavenging activity of

\begin{tabular}{|c|c|c|c|c|c|c|}
\hline \multirow[t]{2}{*}{$\begin{array}{l}\text { Sample } \\
\text { Name }\end{array}$} & \multirow{2}{*}{$\begin{array}{c}\text { Total Phenolic } \\
\text { Content } \\
\text { mg GAE/g } \pm \text { S.D. }\end{array}$} & \multicolumn{2}{|c|}{$\begin{array}{c}\text { Ferric-Reducing Power } \\
\text { (Absorbance at } 700 \mathrm{~nm} \pm \text { S.D.) }\end{array}$} & \multirow[t]{2}{*}{$\begin{array}{c}\text { TAC * } \\
(\text { Mean } \pm \text { S.D. })\end{array}$} & \multicolumn{2}{|c|}{$\begin{array}{c}\text { ABTS Radical Scavenging } \\
\text { Activity (\% } \pm \text { S.D. })\end{array}$} \\
\hline & & $3 \mathrm{mg} / \mathrm{mL}$ & $1 \mathrm{mg} / \mathrm{mL}$ & & $3 \mathrm{mg} / \mathrm{mL}$ & $1 \mathrm{mg} / \mathrm{mL}$ \\
\hline A. oroides & $101.25 \pm 12.41$ & $0.3940 \pm 0.0075$ & $0.1557 \pm 0.0347$ & $619.35 \pm 24.83$ & $51.34 \pm 0.61$ & $20.94 \pm 3.97$ \\
\hline A. aerophoba & $98.63 \pm 3.68$ & $0.8327 \pm 0.0190$ & $0.2444 \pm 0.0104$ & $105.62 \pm 16.55$ & $22.39 \pm 2.78$ & $6.02 \pm 0.95$ \\
\hline A. cannabina & $95.13 \pm 13.47$ & $0.0374 \pm 0.0031$ & $0.0060 \pm 0.0012$ & $76.94 \pm 14.72$ & $1.15 \pm 0.31$ & $4.11 \pm 1.98$ \\
\hline A. polypoides & $117.24 \pm 0.06$ & $1.8050 \pm 0.0617$ & $0.6174 \pm 0.0196$ & $210.75 \pm 35.84$ & $38.18 \pm 1.89$ & $17.67 \pm 1.60$ \\
\hline C. viridis & $86.57 \pm 2.47$ & $0.0860 \pm 0.0059$ & $0.0134 \pm 0.0042$ & $227.48 \pm 25.46$ & $6.85 \pm 1.81$ & $5.61 \pm 1.97$ \\
\hline D. incisa & $96.83 \pm 11.68$ & $0.4517 \pm 0.0298$ & $0.1190 \pm 0.0087$ & 139.07. \pm 57.35 & $17.85 \pm 0.40$ & $6.40 \pm 1.00$ \\
\hline D. avara & $111.95 \pm 6.11$ & $0.7600 \pm 0.0242$ & $0.2710 \pm 0.0200$ & $743.61 \pm 20.28$ & $27.01 \pm 1.19$ & $23.76 \pm 2.20$ \\
\hline E. singularis & $101.75 \pm 4.98$ & $0.5034 \pm 0.0368$ & $0.1294 \pm 0.0097$ & $136.68 \pm 10.61$ & $24.40 \pm 3.01$ & $12.03 \pm 0.80$ \\
\hline I. incisa & $96.28 \pm 3.60$ & $0.3150 \pm 0.0074$ & $0.0860 \pm 0.0055$ & $12.43 \pm 1.55$ & $16.08 \pm 1.07$ & $12.11 \pm 1.00$ \\
\hline I. oros & $97.08 \pm 8.85$ & $0.3920 \pm 0.0296$ & $0.0970 \pm 0.0072$ & $461.65 \pm 12.42$ & $16.54 \pm 1.35$ & $5.86 \pm 2.06$ \\
\hline P. ficiformis & $89.79 \pm 5.66$ & $0.0817 \pm 0.0167$ & $0.0310 \pm 0.0302$ & $155.79 \pm 8.28$ & $17.62 \pm 0.00$ & $4.95 \pm 1.90$ \\
\hline S. spinulosa & $83.51 \pm 8.19$ & $0.6970 \pm 0.0057$ & $0.2390 \pm 0.0068$ & $686.26 \pm 27.14$ & $26.78 \pm 0.87$ & $11.12 \pm 2.55$ \\
\hline Reference & & $3 \mathrm{mg} / \mathrm{mL}$ & $1 \mathrm{mg} / \mathrm{mL}$ & & $3 \mathrm{mg} / \mathrm{mL}$ & $1 \mathrm{mg} / \mathrm{mL}$ \\
\hline Gallic Acid & NT & NT & NT & NT & $98.93 \pm 0.23$ & $98.47 \pm 0.40$ \\
\hline Ascorbic A. & & $0.1928 \pm 0.0042$ & $0.1830 \pm 0.0064$ & $382.5 \pm 17.0$ & NT & NT \\
\hline
\end{tabular}

NT: Not tested; S.D.: Standard Deviation; TAC: Total antioxidant capacity; * Total antioxidant capacity is expressed as mg ascorbic acid equivalent/g extract

Except Axinella cannabina, Petrosia ficiformis and Cliona viridis, all extracts (0.3150 - 1.8050) exhibited stronger antioxidant activity than ascorbic acid (0.1928) in ferric reducing power assay. In phosphomolybdenum assay, total antioxidant capacity of Ircinia variabilis $(619.35 \pm 24.83)$, Dysidea avara $(743.61 \pm 20.28)$, Sarcotragus spinulosa $(686.26 \pm 27.14)$ and Ircinia oros $(461.65 \pm 12.42)$ extracts was found higher than or close to those of Trolox $(382.5 \pm 17.0)$ (Table II). With regard to ABTS radical scavenging activity, among all tested extracts, Agelas oroides extract $(51.34 \pm 0.61 \%)$ exerted the highest ABTS radical scavenging activity at $3 \mathrm{mg} / \mathrm{mL}$ concentration. The other extracts did not show promising radical scavenging activity compared to the reference compound gallic acid. As seen in Table III, Cliona viridis extract had the highest chelating activity $(84.64 \pm 1.73 \%)$. But, Axinella cannabina, Dysidea avara and Sarcotragus spinulosa extracts $(5.19 \pm 1.65$ to $69.09 \pm 0.86)$ at 3 $\mathrm{mg} / \mathrm{mL}$ concentration exhibited a low metal chelating activity in comparison to EDTA. As a result, antioxidant activity of all tested extracts was observed to vary depending on the method used. Because of solubility problems, we could not achieve antioxidant activity tests and evaluate total phenolic content of Ircinia variabilis extract.

Table III

Metal chelating capacities of coral/sponge extracts

\begin{tabular}{|c|c|c|c|}
\hline \multirow[t]{2}{*}{ Sample Name } & \multicolumn{3}{|c|}{$\begin{array}{l}\text { Metal Chelating Capacity } \\
(\% \pm \text { S.D. }) \\
\end{array}$} \\
\hline & $3 \mathrm{mg} / \mathrm{mL}$ & $1 \mathrm{mg} / \mathrm{mL}$ & $0.3 \mathrm{mg} / \mathrm{mL}$ \\
\hline A. oroides & - & - & - \\
\hline A. aerophoba & - & - & - \\
\hline A. cannabina & $5.19 \pm 1.65$ & - & - \\
\hline A. polypoides & - & - & - \\
\hline C. viridis & $84.64 \pm 1.73$ & $84.26 \pm 5.35$ & $84.02 \pm 1.90$ \\
\hline D. incisa & - & - & - \\
\hline D. avara & $61.17 \pm 5.03$ & $50.90 \pm 8.42$ & $49.38 \pm 2.95$ \\
\hline E. singularis & - & - & - \\
\hline I. incisa & - & - & - \\
\hline I. oros & - & - & - \\
\hline P. ficiformis & - & - & - \\
\hline S. spinulosa & $69.09 \pm 0.86$ & $63.90 \pm 1.41$ & $56.02 \pm 1.30$ \\
\hline Reference & $2 \mathrm{mg} / \mathrm{mL}$ & $1 \mathrm{mg} / \mathrm{mL}$ & $0.5 \mathrm{mg} / \mathrm{mL}$ \\
\hline EDTA & $98.87 \pm 0.49$ & $98.02 \pm 1.73$ & $97.46 \pm 0.00$ \\
\hline Gallic Acid & NT & NT & NT \\
\hline
\end{tabular}


Results of the in vitro $\alpha$-glucosidase and $\alpha$-amylase inhibitory studies were presented in Table IV Among all tested marine samples, Dysidea avara showed a strong $\alpha$-glucosidase enzyme inhibitory activity with percentage inhibitions ranging from $94.66-4.87 \%$ for $3000-100 \mu \mathrm{g} / \mathrm{mL}$. We observed that the rest of the extracts did not inhibit $\alpha$-glucosidase enzyme remarkably at $3000 \mu \mathrm{g} / \mathrm{mL}$. Therefore, the lower concentrations of these extracts were not studied for their enzyme inhibitory activities. In this study, the reference substance, acarbose had $98.05 \pm 0.03 \% \alpha$ glucosidase inhibition at $30 \mu \mathrm{g} / \mathrm{mL}$. According to our results, Dysidea avara was found to be the most active sponge, hence $\alpha$-glucosidase inhibitory activity of avarone and avarol which were previously isolated from Dysidea avara was investigated [5]. Both avarone (78.94\%) and avarol (86.18\%) exhibited strong inhibitory activities against $\alpha$-glucosidase enzyme in a dosedependent manner. It is thought that these compounds having sesquiterpene hydroquinone skeleton are responsible for the strong enzyme inhibitory activity of Dysidea avara extract.

On the other hand, $\alpha$-amylase enzyme inhibitory activity of the coral/sponge extracts ranged from $1.32 \%$ to $14.93 \%$ at $3000 \mu \mathrm{g} / \mathrm{mL}$. The inhibition percentage of the reference substance acarbose $(3000 \mu \mathrm{g} / \mathrm{mL})$ on $\alpha$-amylase enzyme was found to be $80.74 \pm 2.53 \%$.

$\alpha$-Glucosidase and $\alpha$-amylase inhibitory activity of coral/sponge extracts

\begin{tabular}{|c|c|c|c|c|c|}
\hline \multirow[t]{2}{*}{ Sample Name } & \multicolumn{4}{|c|}{$\begin{array}{l}\alpha \text {-Glucosidase Inhibitory Activity } \\
\text { Inhibition } \% \pm \text { S.D. }\end{array}$} & \multirow{2}{*}{$\begin{array}{c}\alpha \text {-Amylase Inhibitory Activity } \\
\text { Inhibition } \% \pm \text { S.D. }\end{array}$} \\
\hline & $3000 \mu \mathrm{g} / \mathrm{mL}$ & $1000 \mu \mathrm{g} / \mathrm{mL}$ & $300 \mu \mathrm{g} / \mathrm{ml}$ & $100 \mu \mathrm{g} / \mathrm{mL}$ & \\
\hline A. oroides & $7.55 \pm 2.36$ & - & - & - & $10.50 \pm 0.26$ \\
\hline A. aerophoba & $7.75 \pm 4.05$ & - & - & - & $2.89 \pm 1.39$ \\
\hline A. cannabina & $6.63 \pm 5.52$ & - & - & - & $7.24 \pm 2.23$ \\
\hline A. polypoides & $5.24 \pm 2.01$ & - & - & - & $1.32 \pm 1.79$ \\
\hline C. viridis & $7.45 \pm 0.00$ & - & - & - & $5.87 \pm 3.81$ \\
\hline D. incisa & $16.80 \pm 4.38$ & - & - & - & $6.98 \pm 1.30$ \\
\hline D. avara & $94.66 \pm 0.62$ & $68.03 \pm 2.56$ & $30.81 \pm 8.11$ & $4.87 \pm 1.44$ & $3.58 \pm 3.39$ \\
\hline E. singularis & $15.18 \pm 4.89$ & - & - & - & $4.52 \pm 0.28$ \\
\hline I. incisa & $6.34 \pm 1.89$ & - & - & - & $4.34 \pm 0.56$ \\
\hline I. oros & $7.81 \pm 2.02$ & - & - & - & $10.70 \pm 0.85$ \\
\hline I. variabilis & $4.29 \pm 6.49$ & - & - & - & $5.63 \pm 1.17$ \\
\hline P. ficiformis & $7.35 \pm 5.14$ & - & - & - & $3.29 \pm 2.39$ \\
\hline S. spinulosa & $2.57 \pm 0.00$ & - & - & - & $14.93 \pm 1.97$ \\
\hline \multicolumn{2}{|c|}{ Compounds } & $10 \mu \mathrm{M}$ & $3 \mu \mathrm{M}$ & $1 \mu \mathrm{M}$ & \\
\hline Avarone & & $78.94 \pm 1.38$ & $72.32 \pm 3.73$ & $42.02 \pm 2.51$ & NT \\
\hline Avarol & & $86.18 \pm 1.76$ & $85.51 \pm 2.68$ & $69.15 \pm 1.56$ & NT \\
\hline Reference & $30 \mu \mathrm{g} / \mathrm{mL}$ & $10 \mu \mathrm{g} / \mathrm{mL}$ & $3 \mu \mathrm{g} / \mathrm{mL}$ & $1 \mu \mathrm{g} / \mathrm{mL}$ & $1000 \mu \mathrm{g} / \mathrm{mL}$ \\
\hline Acarbose & $98.05 \pm 0.03$ & $96.13 \pm 0.62$ & $92.40 \pm 1.05$ & $88.45 \pm 3.35$ & $64.50 \pm 1.72$ \\
\hline
\end{tabular}

NT: Not tested; -: No activity; S.D.: Standard Deviation

The relationship between total phenol content, antioxidant and enzyme inhibitory activities of the samples was investigated by Pearson analysis (Table V). Except for total antioxidant activity, a significant, but not very strong relationship was determined between total phenol contents of the samples and ABTS, metal chelating capacities and ferric reducing power. There was generally a negative correlation among the $\alpha$ amylase inhibitory activities of the samples, their antioxidant activities and total phenol content. On the other hand, the $\alpha$-glucosidase enzyme inhibitory activities of the samples were significantly, moderately and positively correlated with their total phenol contents. A positive, significant and moderate relationship was observed between $\alpha$-glucosidase enzyme inhibitory activity and total antioxidant activities of the samples. Diabetes mellitus is a common metabolic disorder in which there are high blood sugar levels over a prolonged period. There are different types and classes of drugs that work in different ways used in the treatment of diabetes such as sulfonylureas, biguanides, meglitinides, thiazolidinediones, $\alpha$-glucosidase inhibitors, bile acid sequestrants. Inhibition of $\alpha$-amylase and $\alpha$-glucosidase, enzymes that play a role in digestion of starch and glycogen, is considered a strategy for the treatment of disorders in carbohydrate uptake, such as diabetes and obesity. Plants are an important source of chemical constituents with potential for inhibition of carbohydrate digestive enzymes and can be used as therapeutic or functional food sources [33]. Many studies were conducted on the enzyme inhibitory effects of marine organisms. Extracts prepared from Echinodictyum pykei, Cymbastela sp., Haliclona sp. and Raspaila sp., and secondary metabolites of various sponge species like callyspongynic acid (from Callyspongia truncate), schulzeines A-C (from Penares schulzei) and penasulfate A (from Penares sp.) are found to be potent inhibitors of $\alpha$-glucosidase [24, $25,31,34,37]$. 
Pearson's correlation coefficients between total phenol contents, antioxidant and enzyme inhibitory acitivities of

\begin{tabular}{|l|c|c|c|c|c|}
\hline & ABTS & $\begin{array}{c}\text { Metal chelating } \\
\text { capacity }\end{array}$ & $\begin{array}{c}\text { Ferric reducing } \\
\text { power }\end{array}$ & $\begin{array}{c}\text { Total antioxidant } \\
\text { capacity }\end{array}$ & $\begin{array}{c}\text { Total phenol } \\
\text { content }\end{array}$ \\
\hline Total phenol content & $0.5035^{* *}$ & $-0.3290^{*}$ & $0.7064^{* *}$ & 0.0869 & \\
\hline Total phenol content activity & 0.1217 & $0.3915^{*}$ & 0.1386 & $0.5220^{* *}$ & $0.4608^{*}$ \\
\hline $\boldsymbol{\alpha}$-amylase inhibitory activity & -0.0348 & -0.2363 & $-0.6045^{* *}$ & 0.1746 & -0.2585 \\
\hline
\end{tabular}

* Correlation is significant at the 0.05 level; ** Correlation is significant at the 0.01 level.

Hitherto, there have been numerous reports on chemical constituents of the tested marine sponges in this study. The genus Petrosia has been reported to have sterols, alkaloids and polyacetylenic molecules [15]. The preliminary chemical screening of Eunicella singularis showed the presence of alkaloids, glycosides, terpenoids, steroids and saponins [10, 11]. Agelas species have been reported to have bromopyrrol-alkaloids in major amounts. Several terpene derivatives, alkaloids and cyclopeptides in Axinella species have been identified by spectral analysis. On the other hand, Ircinia species were found to be quite rich in linear furanoterpenes [13]. Bary et al. reported the presence of tannins, alkaloids, sterols, saponins, flavonoides, free quinones and polyphenols in Cliona viridis [5]. Some brominated isoxazoline alkaloids including aplysinamisin-1, aerophobin-2, isofistularin-3 and aerothion were isolated from the Mediterranean sponges Aplysina aerophoba [38]. Dictyonella species are rich in sterols, fatty acids, saponins and triterpenoids [7]. Sesquiterpenoids such as avarol and avarone having several biological activities were isolated from Dysidea avara by Ferrandiz et al. [14].

On the other hand, oxidative stress, is one of the major problems observed in diabetic patients that leads to severe complications. Therefore, discovery of antidiabetic compounds/extracts having antioxidant effects is one of the targets for finding new generation antidiabetic drugs. Erdogan Orhan et al. [13] and Aktaş et al. [2] have studied on the antioxidant activities of marine sponges collected from Mediterranean coast of Turkey. 2,2-diphenyl-1-picrylhydrazil (DPPH), superoxide (SO) and nitric oxide (NO) radical scavenging activities of the sponge extracts have been determined and dose dependent radical scavenging activity has been observed. In our study, total antioxidant capacity, ferric reducing power and metal chelating capacity of Dysidea avara extract was found to be promising compared to the standard antioxidant compounds EDTA, Trolox and ascorbic acid.

This is the first report on the in vitroantidiabetic potentials of Turkish marine organisms. In this study, Dysidea avara showed a strong $\alpha$-glucosidase enzyme inhibitory activity with percentage inhibitions ranging from $94.66-4.87 \%$ for $3000-100 \mu \mathrm{g} / \mathrm{mL}$. During the course of our studies on Turkish marine sponges, avarol and avarone isolated from the methanol extract of D. avara [3] exhibited a potent $\alpha$-glucosidase inhibitory activity. Previous studies also showed that avarol has highly effective $\alpha$-glucosidase enzyme inhibitory activity [17].

Avarol is a marine natural product known for more than 40 years $[8,21]$ that is present in large amounts only in the sponge Dysidea avara [23]. This molecule possesses a rigid sesquiterpene skeleton and a reactive hydroquinone moiety, which can interfere with reactive oxygen species production and the redox status of cells. Avarol and avarone exhibits a wide array of biological activities including antibacterial, antifungal, antioxidant, antiplatelet, antipsoriatic, antiviral and antitumour effects [3, 9, 36, 39]. Additionally, some alkyl(aryl)thio and alkyl(aryl)amino derivatives of avarol and avarone (oxidised form of avarol) have exhibited moderate acetylcholinesterase inhibitory activity which has been shown to be essential to delay the onset of Alzheimer's disease [28, 29].

\section{Conclusions}

In this study, total phenolic content, antioxidant activities (total antioxidant capacity, ferric reducing power and metal chelating capacity) and in vitro antidiabetic effects of various marine organisms from the Mediterranean were tested, and Dysidea avara was found to be the most promising organism in terms of these activities. On the other hand, its avarol and avarone content have been found to be responsible for strong $\alpha$-glucosidase enzyme inhibitory activity of D. avara. In conclusion, the sponge Dysidea avara found in Mediterranean Sea coasts can be evaluated as a new natural source in the treatment of diabetes mellitus.

\section{Conflict of interest}

The authors declare no conflict of interest.

\section{References}

1. Aktaş N, Genc Y, Gozcelioglu B, Konuklugil B, Harput US, Radical scavenging effect of different marine sponges from Mediterranean coasts. Rec Nat Prod., 2013; 7(2): 96-104.

2. Aktaş N, Gözcelioğlu B, Konuklugil B, Qualitative detection of some secondary metabolites from Turkish marine sponges collected in Kemer. FABAD J Pharm Sci., 2011; 36: 129-136.

3. Aktaş N, Gözcelioğlu B, Zang Y, Lin WH, Konuklugil $\mathrm{B}$, Avarone and avarol from the marine sponge 
Dysidea avara Schmidt from Aegean coast of Turkey. FABAD J Pharm Sci., 2010; 35: 119-123.

4. Ali H, Houghton PJ, Soumyanath A, $\alpha$-Amylase inhibitory activity of some Malaysian plants used to treat diabetes; with particular reference to Phyllanthus amarus. J Ethnopharmacol., 2006; 107(3): 449-455.

5. Bary K, Elamraoui B, Bamhaoud T, Chemical characterization of Cliona viridis: Sponge of Atlantic Moroccan Coast. Int J Inno Sci Res., 2016; 26(1): 14-22.

6. Braekman JC, Daloze D, Chemical and biological aspects of sponge secondary metabolites. Phytochem Rev, 2004; 3: 275-283.

7. Ciminiello P, Fattorusso E, Magno S, Mangoni A, Pansini M, Incisterols, a new class of highly degraded sterols from the marine sponge Dictyonella incisa. J Am Chem Soc., 1990; 112: 3505-3509.

8. De Rosa S, Minale L, Riccio R, Sodano G, The absolute configuration of avarol, a rearranged sesquiterpenoid hydroquinone from a marine sponge. J Chem Soc Perkin Trans., 1976; 1: 1408-1414.

9. De Rosa S, Tommonaro G, Bioactive marine prenylated quinones/quinols. In: Studies in Natural Products Chemistry (Bioactive Natural Products), Elsevier, Amsterdam, 2012; 163-218.

10. Deghrigue $\mathrm{M}$, Dellai A, Bouraoui A, In vitro antiproliferative and antioxidant activities of the organic extract and its semi-purified fractions from the Mediterranean Gorgonian Eunicella singularis. Int J Pharm Pharm Sci., 2013; 5: 432-439.

11. Deghrigue M, Festa C, Ghribi L, D'auria MV, Marino S, Jannet HB, Said RB, Bouraoui A, Pharmacological evaluation of the semi-purified fractions from the soft coral Eunicella singularis and isolation of pure compounds. DARU J Pharm Sci., 2014; 22(1): 64-71.

12. Dinish TCP, Madeira VMC, Almeida LM, Action of phenolic derivatives (acetaminophen, salicylate and 5-aminosalycilate) as inhibitors of membrane lipid peroxidation and as peroxyl radical scavengers. Arch Biochem Biophys., 1994; 315(1): 161-169.

13. Erdogan Orhan I, Ozcelik B, Konuklugil B, Putz A, Kaban UG, Proksch P, Bioactivity screening of the selected Turkish marine sponges and three compounds from Agelas oroides. Rec Na. Prod., 2012; 6(4): 356-367.

14. Ferrandiz L, Sanz MJ, Bustos G, Paya M, Alcaraz JM, Dande-Rosa S, Avarol and avarone, two new anti-inflammatory agents of marine origin. Eur $J$ Pharmacol., 1994; 253(1-2): 75-82.

15. Ferretti C, Vacca S, Ciucis C, Marengo B, Duckworth AR, Manconi R, Pronzato R, Domenicotti C, Growth dynamics and bioactivity variation of the Mediterranean demosponges Agelas oroides (Agelasida, Agelasidae) and Petrosia ficiformis (Haplosclerida, Petrosiidae). Mar Ecol., 2009; 30: 327-336.

16. Gözcelioğlu B, Konuklugil B, Qualitative detection of some secondary metabolites from three Turkish marine sponges. FABAD J Pharm Sci., 2012; 37: 73-78.

17. Hecht SM, Locke E, Inhibition of carbohydrates metabolism by quinone compounds. US Pat. 6075057 A. University of Virginia patent foundation, Virginia, USA, 2000.

18. Konuklugil B, Gözcelioğlu B, Antimicrobial activity of marine samples collected from the different coasts of Turkey. Turk J Pharm Sci., 2015; 12(3): 337-344.
19. Lam SH, Chen JM, Kang CJ, Chen CH, Lee S, $\alpha$ Glucosidase inhibitors from the seeds of Syagrus romanzoffiana. Phytochemistry, 2008; 69(5): 11731178.

20. Meot-Duros L, Le Floch G, Magne C, Radical scavenging, antioxidant and antimicrobial activities of halophytic species. J Ethnopharmacol., 2008; 116(2): 258-262.

21. Minale L, Riccio R, Sodano G, Avarol, a novel sesquiterpenoid hydroquinone with a rearranged drimane skeleton from the sponge Dysidea avara. Tetrahedron Lett., 1974; 15(38): 3401-3404.

22. Munro MHG, Blunt JW, Lake RJ, Litaudon M, Battershill CN, Page MJ, From seabed to sickbed: What are the prospects?, in: Sponges in Time and Space, Balkema, Rotterdam, 1994; 473-484.

23. Müller WEG, Diehl-Seifert B, Sobel C, Bechtold A, Kljajić Z, Dorn A, Sponge secondary metabolites: Biochemical and ultrastructural localization of the antimitotic agent avarol in Dysidea avara. J Histochem Cytochem., 1986; 34(12): 1687-1690.

24. Nakao Y, Maki T, Matsunaga S, Van Soest RW, Fusetani N, Penasulfate A, a new alpha-glucosidase inhibitor from a marine sponge Penares sp. J Nat Prod., 2004; 67(8): 1346-1350.

25. Nakao Y, Uehara T, Matsunaga S, Fusetani N, Van Soest RWM, Matsunaga S, Callyspongynic acid, a polyacetylenic acid which inhibits $\alpha$-glucosidase, from the marine sponge Callyspongia truncata. $J$ Nat Prod., 2002; 65(6): 922-924.

26. Oyaizu M, Studies on products of browning reactionsantioxidative activities of products of browning reaction prepared from glucosamine. Jpn J Nutr., 1986; 44: 307-315.

27. Öner Ö, Ekiz G, Hameş EE, Demir V, Gübe Ö, Özkaya FC, Yokeş MB, Uzel A, Bedir E, Cultivable spongeassociated Actinobacteria from coastal area of Eastern Mediterranean Sea. Adv Microbiol., 2014; 4(6): 306316.

28. Pejin B, Iodice C, Tommonaro G, Bogdanovic G, Kojic V, De Rosa S, Further in vitro evaluation of cytotoxicity of the marine natural product derivative 4'-leucine-avarone. Nat Prod Res., 2014; 28(5): 347350.

29. Pejin B, Iodice C, Tommonaro G, De Rosa S, Synthesis and biological activities of thio-avarol derivatives. J Nat Prod., 2008; 71(11): 1850-1853.

30. Prieto P, Pineda M, Aguilar M, Spectrophotometric quantitation of antioxidant capacity through the formation of a phosphomolybdenum complex, specific application to the determination of vitamin E. Anal Biochem., 1999; 269(2): 337-341.

31. Ramanjooloo A, Cresteil T, Lebrasse C, Beedessee G, Oogarah P, Van Soest RWM, Marie DEP, $\alpha$ Glucosidase inhibitory activity of marine sponges collected in Mauritius waters. Nat Prod Res., 2015; 29(4): 383-387.

32. Re R, Pellegrini N, Proteggente A, Pannala A, Yang $\mathrm{M}$, Rice-Evans C, Antioxidant activity appliying an improved ABTS radical cation decolorization assay. Free Radic Biol Med., 1999; 26(9-10): 1231-1237.

33. Sales PM, Souza PM, Simeoni LA, Silveira D, $\alpha-$ Amylase inhibitors: a review of raw material and 
FARMACIA, 2021, Vol. 69, 1

isolated compounds from plant source. JPPS, 2012; 15(1): 141-183.

34. Saludes JP, Lievens SC, Molinski TF, Occurrence of the $\alpha$-Glucosidase inhibitor 1,4-dideoxy-1,4imino-D-arabinitol and related iminopentitols in marine sponges. J Nat Prod., 2007; 70(3): 436-438.

35. Sipkema D, Franssen MCR, Osinga R, Tramper J, Wijffels RH, Marine sponges as Pharmacy. Mar Biotechnol., 2005; 7(3): 142-162.

36. Sladić D, Gašić MJ, Reactivity and biological activity of the marine sesquiterpene hydroquinone avarol and related compounds from sponges of the order Dictyoceratida. Molecules, 2006; 11(1): 1-33.

37. Takada K, Uehara T, Nakao Y, Matsunaga S, Van Soest RWM, Fusetani N, Schulzeines A-C, New $\alpha-$ glucosidase inhibitors from the marine sponge Penares schulzei. J Am Chem Soc., 2004; 126(1): 187-193.
38. Thoms C, Wolff M, Padmakumar K, Ebel R, Prokscha $\mathrm{P}$, Chemical defense of Mediterranean sponges Aplysina cavernicola and Aplysina aerophoba. Z Naturforsch., 2004; 59(1-2): 113-122.

39. Tommonaro G, Pejin B, Iodice C, Tafuto A, De Rosa S, Further in vitro biological activity evaluation of amino-, thio- and ester-derivatives of avarol. $J$ Enzyme Inhib Med Chem., 2015; 30(2): 333-335.

40. Topaloğlu B, Evcen A, Updated checklist of sponges (Porifera) along the coasts of Turkey. Turk J Zool., 2014; 38(6): 665-676

41. Zongo C, Savadogo A, Ouattara L, Bassole IHN, Ouattara CAT, Ouattara AS, Barro N, Koudou J, Traore AS, Polyphenols content, antioxidant and antimicrobial activities of Ampelocissus grantii (Baker) Planch. (Vitaceae): A medicinal plant from Burkina Faso. Int J Pharm., 2010; 6(6): 880-887. 